http://heanoti.com/index.php/hn

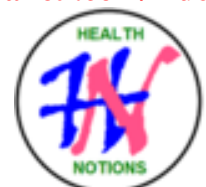

RESEARCH ARTICLE

URL of this article: http://heanoti.com/index.php/hn/article/view/hn30404

\title{
The Effect of Family Economy on Availability of Family Toilet in Luwohu Village, Bone
} Bolango District

\author{
Bun Yamin M. Badjuka ${ }^{1(\mathrm{CA})}$ \\ ${ }^{1(\mathrm{CA})}$ Lecturer of Midwifery Department, Health Polytechnic of Gorontalo, Indonesia; \\ bunyaminbadjuka@gmail.com (Corresponding Author)
}

\begin{abstract}
Toilet facilities that do not meet health requirements can cause infectious diseases to the society. Toilet is residential facility. An average economy condition causes the family unable to build facilities / own defecation place because family income prioritizes more on daily family needs like meal cost and education cost. Therefore eventhough that family has awareness and desire but can not afford to build feces disposal facilities because of fund difficulty. The purpose of this research is to know the effect of family economy to the availability of family toilet at Luwohu Village of Bone Bolango Disctrict. The type of this research was analytic observational research with cross sectional research design. Chi square test result showed $\mathrm{X}^{2}$ countation (7.25) was bigger than $\mathrm{X}^{2}$ table (3.841), with $\mathrm{p}$ value $=0.007$ which means that there was a very significant effect between family economy to the availability of family toilets at Luwohu Village, with other words the higher family economy was, family toilets were more increasingly available. It is advised that the Government of Luwohu Village, should be able to give motivation to the society to have family toilets or add public facilities like public toilets at least two in every environment and Public Health Centers through sanitation officer should give counseling and techincal assistance at building family toilet and the head of family should work hard to have family toilet at least in a simple form but meets the health requirements.
\end{abstract}

Keywords: Family economy, Toilet, Availabilty of toilet

\section{INTRODUCTION}

\section{Background}

The quality of clean water used by the society is very influenced by the quality of that water sources besides the water source type used. One of the most used water sources by the society is dig well. Dig well is one of the clean water supply sources for people in rural areas, and urban areas. Dig well provides water that comes from the soil layer that is relatively close to ground level, therefore easily exposed to contamination through seepage that comes from human excrement, animals, and for domestic household needs. Digging wells as a source of clean water must be supported by construction conditions, the location requirements for the construction of a dug well, this is needed so that the quality of the well water is dug safely in accordance with the rules set ${ }^{(1)}$.

The types of water sources for all household needs in Indonesia in general are protected dug wells (29.2\%), pump wells (24.1\%), and tap water (19.7\%). In urban areas, more households use water from pump wells $(32.9 \%)$ and tap water $(28.6 \%)$, while in rural areas more use protected dug wells $(32.7 \%)^{(2)}$. Physical conditions of the wells digging and the bacteriological quality of well water. One of the diseases caused by bacteriological conditions that do not meet the water requirements is diarrhea, especially in infants the absence of clean water results in diarrhea diseases ${ }^{(3)}$.

The number of diarrhea cases in Gorontalo Province amounted to 16,206 cases and for Bone Bolango district amounted to 2,128 cases with the most cases in Kabila Public Health Center as many as 309 cases. Kabila Community Health Center is one of the technical implementation units of Health Office of Bone Bolango District that used the most dug wells as a source of clean water, which was 2,442 dug wells consisting of 1,831 protected dug wells and 611 uncovered wells ${ }^{(4)}$. Dug wells that do not have good construction can be a 
risk factor for the transmission of diarrheal diseases. The results of a preliminary study of 10 respondents in the Kabila Community Health Center working area, 100\% used ground water for drinking and cooking.

\section{METHODS}

The type of this research was analytic observational research with cross sectional research design. The research was conducted in 1 month which was on $1^{\text {st }}-30^{\text {th }}$ May 2015 . The research place was at Luwohu Village of Bone Bolango Disctrict. The population in this research are all houses in Luwohu Village, there were 96 houses. The subject research were all houses in Luwohu Village, there were 96 houses. The primary data in this research was obtained from direct observation result in the research location. The secondary data in this research were the data obtained from literature and related institutions.

The processing technique and data presentatoin of this research were done through the following processes: Coding was entering respondent's code in questionairre sheet to simplify finding back the respondent's address in order to follow-up. Editing was data editing which was examining all data in questionairre sheet whether it has been filled objectively. Tabulation which was processing data into table master. The data from table master was presented in the form of distribution table, cross table, narrative, or images to simply analyzing data. This research used univariate and bivariate data analytic technique and then processed by using statistical program.

\section{RESULTS}

\section{Characteristic of Respondents}

Table 1. Distribution of home resident type in Luwohu Village of Bone Bolango District 2015

\begin{tabular}{ccc}
\hline Home type & Frequency & Percentage \\
\hline Permanent & 87 & 90.6 \\
Non permanent & 9 & 9.4 \\
\hline Total & 96 & 100.0 \\
\hline
\end{tabular}

Table 1 showed that Types of Home Residents of Luwohu Village Bone Bolango District The highest number of permanent houses in 2015 was equal to $90.6 \%$.

Table 2. Distribution of the condition of family economy in Luwohu Village Bone Bolango District 2015

\begin{tabular}{ccc}
\hline Family economy & Total & Percentage \\
\hline$<$ Rp 1.600.000,- & 50 & 52.1 \\
$\geq$ Rp. 1.600.000,- & 46 & 47.9 \\
\hline Total & 96 & 100.0 \\
\hline
\end{tabular}

Table 2 showed that the condition of family economy in Luwohu Village Bone Bolango District evenly $(52.1 \%)$ lower or less than Rp. 1.600.000,- per month.

Table 3. Distribution of availability of family toilets in Luwohu Village of Bone Bolango District 2015

\begin{tabular}{ccc}
\hline The availability of family toilet & Total & Percentage \\
\hline Available & 74 & 77.1 \\
Unavailable & 22 & 22.9 \\
\hline Total & 96 & 100.0 \\
\hline
\end{tabular}

Table 3 showed that the availability of family toilet in Luwohu Village $22.9 \%$ doesn't have family toilets.

\section{Analysis of family economy to the availability of family toilet}

Table 4. The effect of family economy to the availability of family toilet in Luwohu Village Bone Bolango District 2015

\begin{tabular}{|c|c|c|c|c|}
\hline \multirow{2}{*}{ Family Economy } & \multicolumn{2}{|c|}{ Availability of Family Toilet } & \multirow{2}{*}{ Total } & \multirow{2}{*}{$X_{\text {Count }}^{2}$} \\
\hline & Available & Unavailable & & \\
\hline$<\operatorname{Rp} 1.600 .000,-$ & $33(66.0 \%)$ & $17(34.0 \%)$ & $50(100 \%)$ & \multirow{2}{*}{7.25} \\
\hline$\geq$ Rp. $1.600 .000,-$ & $41(89.1 \%)$ & $5(10.9 \%)$ & $46(100 \%)$ & \\
\hline Total & 74 & 22 & $96(100 \%)$ & \\
\hline
\end{tabular}


Table 4 showed that respondents who have a family economy of more than or equal to Rp. 1.600.000, 46 households $(47.9 \%)$ mostly $(89.13 \%)$ have latrines while respondents who have a family economy are less than Rp. 1.600.000, as many as 50 households $(52.08 \%)$ have fewer latrines, which was $66.0 \%$. Chi square test results show $\mathrm{X}^{2}$ count (7.25) greater than $\mathrm{X}^{2}$ table (3.841), with a value of $\mathrm{p}=0.007$ which means that there was a very significant influence between the family economy on the availability of family latrines in Luwohu Village, Bone Bolango District, with in other words the higher the family economy, the more available family toilets.

\section{DISCUSSION}

The behavior of the people in Luwohu Village of Bone Bolango District in responding to the availability of family latrines according to the results of the above research is still not good, so that it affects the environment, therefore the program implementation of behavior change is needed such as education and latrine provision by the local government. Knowledge of the people of Molintogupo Village gives an ability to explain correctly the meaning of latrines which are known not only to know the knowledge of latrines, not just to be able to mention, but the person must be able to interpret correctly the knowledge of the latrine that is known. People who have understood the object or material, must be able to explain, conclude, and predict the object being studied.

\section{Family Economy}

This study shows that the economic situation of the family in Luwohu Village, Botupingge District is on average $(52.1 \%)$ lower or less than Rp. 1.600 .000 per month. The cause of low family income, among others, from 578 inhabitants, $58.1 \%$ did not work, while the main type of occupation of the population was farmers with critical land on the slopes with limited area. Indicators of family economic capacity in Luwohu Village can also be seen from home ownership. From 166 family heads, who owned 96 households $(57.8 \%), 7$ of them were still simple, while 70 households $(42.2 \%)$ were hitching or not.

\section{Availability of Family Toilet}

Data from this study indicate that the availability of family toilets in Luwohu Village $22.9 \%$ does not have family latrines. The average residential density in Luwohu Village is 6 houses. Thus the number of people who are not served by family latrines is 22 houses 6 people (132 people) who have the potential to pollute the environment by removing feces in any place, namely in the river, in the fields and in the bushes. A good method of disposal of feces is to use a toilet that meets the following requirements: Does not pollute the soil or the surface of the soil, does not pollute ground water that might enter a spring or well, does not contaminate surface water, feces are not affordable by flies, cockroaches and other animals, toilets must be removed from odor or unsightly conditions and the method of making and operating must be simple and inexpensive ${ }^{(5)}$.

\section{The Effect of The Family Economy on The Availability of Family Toilets}

Data from the research shows that respondents who have a family economy of more than or equal to Rp. $1.600 .000,46$ households $(47.9 \%)$ mostly $(89.13 \%)$ have latrines while respondents who have a family economy are less than Rp. 1.600.000, as many as 50 households (52.08\%) have fewer latrines, which is $66.0 \%$. In terms of cost aspects, the type of toilet recommended for a community group or family must be simple, acceptable, and economical in making, maintaining or replacing it if its needs increase without overriding healthy latrine standards. The choice of the type of toilet that best suits local needs must take into account the cost element. Sewerage systems with toilets equipped with flushers are expensive and may be beyond the reach of the economic capacity of most community members. Meanwhile, it may be on the other hand that someone chooses the most primitive type of toilet without any cost at all, but that method has risks. That is, this method can cause transmission of disease and death and result in economic losses. Between these two extreme conditions must be obtained a solution that will provide the greatest health protection as well as affordable by the community economy $^{(6)}$.

\section{CONCLUSION}

Most of the population have family economic abilities with a category less than the minimum wage of Gorontalo Province, most of the population of Luwohu Village in 2015 had family toilets and there was a very significant influence between the family economy and the availability of family latrines in Luwohu Village of Bone Bolango District. 
The Government of Luwohu Village, may be able to provide motivation to the community to have family latrines or add public facilities in the form of adding to the toilet in every neighborhood at least 2 pieces. The head of the family should try to have a minimum family toilet in a simple form but meet health requirements and The Public Health Center through sanitation officers should be able to provide counseling and technical assistance in the construction of family toilets.

\section{REFERENCES}

1. BPS-Gorontalo. Gorontalo in Figures (Gorontalo dalam Angka). Gorontalo: BPS-Gorontalo; 2014.

2. MoH-RI. Basic Health Research 2013 (Riset Kesehatan Dasar 2013). Jakarta: MoH-RI; 2013.

3. Basuki. Guidelines for Field Study of Fecal Disposal and Wastewater in Sanitation / Environmental Health Education Institutions (Pedoman Bidang Studi Pembuangan Tinja dan Air Limbah Pada Institusi Pendidikan Sanitasi/Kesehatan Lingkungan). MoH-RI, Jakarta; 1991.

4. Nur MS. Health Profile of Gorontalo Province (Profil Kesehatan Provinsi Gorontalo). Gorontalo: Dinkes Prov. Gorontalo; 2008.

5. Sugandhy A, et al. Environmental Development Sustainable Development (Pembangunan Berkelanjutan Berwawasan Lingkungan). Jakarta: Bumi Aksara; 2007.

6. Soeparman, et al. Fecal Disposal and Liquid Waste (Pembuangan Tinja dan Limbah Cair) Jakarta: EGC; 2001. 